\title{
STUDY ON THE RELATIONSHIP BETWEEN PARTICIPATORY MANAGEMENT IN SCHOOLS AND TEACHERS' DEVELOPMENT OF SOCIAL CAPITAL FROM MANAGERS AND TEACHERS VIEWS OF SECONDARY SCHOOL TEACHERS KARAJ DISTRICT 3
}

\author{
E. Abbasi ${ }^{1 *}$ and S. Keshavarz Noori ${ }^{2}$ \\ ${ }^{1}$ Academic member of Khawrazmi University, Iran \\ ${ }^{2}$ Islamic Azad University, Karaj branch, Alborz, Iran
}

Published online: 15 May 2016

\begin{abstract}
The aim of this study was to examine the relationship between social capital growths with use of participatory management in schools in Karaj. The research method was descriptive and correlational. The sample size in the current survey included all principals and teachers in secondary schools in District 3 city of Karaj in 2014-2015. The sample size was determined using Cochran formula as sample of 305 people. Stratified sampling method used is proportional to population size. In order to measure the variables used in the study two researcher made questionnaires of participative management by Kritner (2006) and social capital of Vilanova and Chosa (2003) were used. The validity and reliability of both questionnaires were determined and approved by interviewing of several professors by Cronbach alpha for participative management (0.85) and social capital (0.87). For the analysis, descriptive and inferential statistical methods (Pearson correlation coefficient, independent t-test and ANOVA) were used.
\end{abstract}

Author Correspondence, e-mail: effattabbasi@gmail.com

doi: http://dx.doi.org/10.4314/jfas.v8i3s.178 
The results showed that there were correlation among participatory management and its components (decision-making, communication, collaborative, participative leadership, corporate structure and corporate control) and social capital among administrators and teachers in secondary schools in District 3 of Karaj. Independent t-test results showed that the there were significant differences among views of male and female employees about corporate governance and social capital. One-way ANOVA analysis of variance showed that there were no significant difference among comments about the staff participatory management and social capital in terms of education, work experience and age.

Keywords: corporate governance; social capital; institutional trust.

\section{INTRODUCTION}

Social capital is a fundamental concept that in recent decades has been accepted as a valuable asset to maintain healthy communities, robust organizations and vibrant civil societies (Timberlake, 2005). The social capital is potential accumulation or actual sources (such as expertise and skills) that relates to the ownership of a durable network of more or less institutionalized relationships among those with membership in a group. Social capital is embodied in the relationships between people and occurs when social capital ceates that relationships between individuals transform in a manner that action facilitates (Manzoor and Yadipour, 208). During the last 25 years the concept of social capital increasingly has attracted the attention of scientists and researchers from different disciplines. The importance of attention to social capital is based on the role that social capital plays in production and increase human capital, economic, environmental (Sharifian Sani, 2001). Social capital, unlike human capital or physical capital, is a concept that is far beyond the assets that a person owns and has areas in which the relationships and interactions are responsible for main task. In other words, today, social capital plays far more important role of physical and human capital in organizations and communities and networks of social relations, group cohesion among people, organizations, and individuals and organizations are organized. In the absence of social capital other investors lose their effectiveness. Without social capital pave the way for the development, economic and cultural development, uneven and difficult (Baker, 2003). Inkpen and Tsang (2005) define addressing organizational social capital as "Total resources within, available through and derived from the network of relationships that individuals or organizations possess". This definition considers network of relations as a valuable source (as quoted by Lazarova and Taylor, 2008). Schneider (2009) defined organizational social capital 
as "institutionalized networks based on trust in the social organization or a non-profit organization supports and cause the organization to achieve its goals". According to him, social capital is crucial for the development and survival of non-profit organizations. The above definition of social capital organization focused on type of external capital. Social capital is not a one-dimensional concept and in previous studies, social capital has been tested in various aspects. Social capital creates much interest in organizational life. In organizations that there is social capital, it is possible to observe participative open atmosphere, responsive staff, productivity, organizational commitment, a culture of compromise, teamwork, job satisfaction and participation in decision making (Nadi and Moshfeghi, 2006). Vilanova and Josa (2003) defined social capital, managerial phenomenon, which has characteristics including trust (norms), common values and behaviors, relationships, cooperation, understanding, mutual obligation and mutual network. In their view, social capital not only can not be there in the absence of one of these properties, but can not imagine an organization without some of the features of social capital to do its job. In their view, action social capital, facilitate collaborative and increase the value of intangible assets.

Networks: One of the most important aspects of social capital is being membership in networks. Networks are important in the development of identity and self-concept. Through networks that people create their communications with others. Prusak and Kehen suggested that a sense of belonging with praise and recognition from co-important organizational rewards for employees (Hassanpour and Niakian, 2007).

Trust: Pors (2007) believes that when personal or institutional relationships of trust be high, people generally tend to participate in social exchange and, in particular, cooperation, trust and increase engagement, cost reduction, reduced opportunism, and improves organizational performance (Sharifian Thani, 2005).

Values: According to this approach, social capital is a subjective phenomenon that the set of values and attitudes about how to create an effective and decisive people communicate with each other is formed. (Mohammadi, 2005).

Relationships: social relations are informational channels that reduce the amount of time and investment required to data collection (Demori et al., 2008).

Collaboration: Collaboration is an expression of a collective action with others in the community or members of group are acting in common. Cooperation is a precondition coordination, which is essential for innovation and competitive success (Mohammadi, 2005). 
Commitment: This aspect of social capital includes credit cards, which is thought to derive from the expectations and reciprocal obligations (Zare Khalili, 2011).

Mutual understanding: empathy or understanding leads the unity of hearts, too, but more order, finding common sense (sayadi, 2009). Extensive changes including growing needs for information and training needs necessary for innovation, continuous improvement, changes to the organizational design of flat and flexible, interconnected networks between organizations and customers, suppliers and competitors, that leaders of organizations, social capital as an organizational competencies are identified, which promotes trust and relationships between members of the organization and improving relationships with people outside of your organization within the organizational structure. On the other hand, in order to create effective management, it seems that the employees (managers and employees) have more social capital. One of the reasons that makes leadership more effective is that both the leaders have wider social capital. In fact, more extensive social capital can be one of the results of participatory management style behavior (Hoffman et al., 2002). Participative management is the process of cooperation and influence employee decision-making process at different levels of the active and real and involvement of the voluntary and conscious mental and team goals and efforts to achieve the goals that motivate employees and self-responsibility and creativity (Sadeghifard ad Naghavi, 2003). Participatory management means participating staff in different companies, planning, decision-making, implementation, monitoring and evaluation (Feizi, 2006). Participatory management components are participatory decision making, communication, collaborative, participatory leadership, corporate structure, and corporate control.

Participatory decision making: a participative decision making is kind of decision-making and its characteristics, is data collection by teachers at the school level and provide consultative decision making problems and their solution by teachers (Kritner and Kiniki, 2006).

Community Involvement: A kind of communication that the characteristics of participatory communication, intimacy and mutual respect between administrators and teachers, group communication between teachers, teachers' attention to social problems and organizing work by teachers (Kritner and Kiniki, 2006).

Participatory leadership: It is kind of leadership that its characteristics is participatory leadership through advance works and motivating teachers, getting things done on the basis of trust and responsibility, attention and importance to the labor process, according to the 
abilities and expertise of teachers, according to needs intellectual independence and autonomy of teachers (Kritner and Kiniki, 2006).

Participatory structure: a kind of structure that purpose cooperative structure of the characteristics of the delegation of authority and empowerment subordinates (Kritner and Kiniki, 2006).

Participatory control: participatory monitoring control is a kind of control that its characteristics are monitoring the work of teachers and internal control self-assessment by teachers (Kritner and Kiniki, 2006). Then, as domestic and foreign research associated with variables research will be discussed. Dad sepahi (2014) that in a study showed that there was a significant positive correlation fits between social capital and participatory management (0.57). The dimensions of social capital had a positive and significant correlation between social investment and partnership management. Faizi et al (2010) in study entited "the relationship between social capital and participatory management at the University of Medical Sciences" achieved these results that there is a direct correlation between the level of trust and participatory management (0.48) and also between intimacies with management partnership (0.57). Communications networks related indirectly through trust and intimacy with participatory management (0.39). In relation to the independent variables, the results showed that the level of trust and communication networks of moderate and intimacy was too low. These results have been evaluated as the dependent variable or participatory management was at low level. Andishmand (2009) in a study entitled "Identifying the components of social capital in universities in order to present a model to improve it" achieved the results that main components of commitment and belonging, power, leadership and management, benevolence and generosity, creating relationship between knowledgeable people and those who need their knowledge, accessibility to individuals and groups are required, but a higher mean score on the components of praise and gratitude, justice, orientation toward collective objective, fostering innovation and creativity, correlation in the entire organization and cooperative management had the lowest mean and represent in these areas was undesirable. The results showed that there was no significant difference between respondents' opinions gtom fifferent aspects of concerning gender, education and work experience, but regarding the variables of scientific rank and university location is not the same, so scientific rank, the highest social capital (professors) and minimum (coach). Also, the variable place of service, the city of Zarand and Kerman, respectively, had the highest and lowest social capital respectively. Nateghpour and Firoozabadi (2006) in a study entitled "Factors affecting the development of 
social capital and meta-analysis" concluded that the age, education, marital status, employment and income but with an element of trust with other elements such as social capital Knowledge and attention to public affairs (0.35), reliability (0.49), formal and informal partnerships (0.32) had a direct correlation. And men in knowledge and attention to public affairs and formal participation had a greater role than women and informal participation of women was higher and in terms of trust there was no difference between men and women. Adams (2006) in his thesis entitled "The link between social capital and organizational learning invesigated an empirical examination of the antecedents and consequences of two new structures "to explore the role of knowledge management and organizational learning. Thus, the knowledge management system is as a bridge to fill the gap between social capital and organizational learning and facilitate the communication between them. Hammer et al, (2012) in a study entitled "The relationship between transformational leadership and social capital in hospitals in Germany" concluded that there was a significant correlation between transactional leadership styles of executive management with social capital (0.68). The results showed that transformational leadership explained $36 \%$ of the social capital. Hamzezadeh Afkhan et al (2013) in a study examined the relationship between organizational justice and social capital and concluded that there was a significant positive correlation in all aspects of its organizational justice and organizational social capital. The aims of this study was to investigate the correlation between the use of participatory management in schools and social capital, participation in decision-making and the growth of social capital, participatory communications and the growth of social capital, participative leadership and social capital growth, partnership structure in the schools and the growth of social capital, and correlation between partnership control and the growth of social capital in the school administrators and teachers in secondary schools are in District 3 of Karaj.

\section{The sample size and sampling}

The study consisted of all managers and teachers of secondary schools in District 3 of Karaj city, which according to the latest data, the number of them were 918 persons ( 881 teachers, 37 principals). of the population of the study, the sample of 268 teachers were selected using Cochran sampling formula and simple random sampling. Considering the small number of managers, the total number of managers $(n=37)$ investigated completely. To sample after sample size of simple random sampling method was used. 


\section{RESEARCH TOOLS}

Participatory management Scale according to five dimensions (decision making, communication, leadership, structure and supervision) was made by researchers. The scale containied 26 questions that were based on the conceptual distinction between 7 points range and measured five dimensions (decision making, communication, leadership, structure and control). The reliability of collaborative management questionnair was determined through Cronbach alpha (0.85) which represents the desired level of reliability of the questionnaire. The second tool used in this study was a questionnaire of Vilanova and Chosa (2003) with 28 questions of social capital that measured seven dimensions of trust, relationships, work, values, networks, commitment and understanding. Overall reliability was determined 0.87 which represented the desired level of reliability of the questionnaire.

\section{Data analysis methods}

In order to analyze the data, the methods of descriptive statistics (frequency, percentage) and inferential statistics such as Pearson correlation coefficient was used.

\section{Research findings}

First hypothesis: there was correlation between the use of participatory management in schools and social capital from administrators and teachers views in secondary schools in District 3 of Karaj.

Table 1. Correlation between the use of participatory management in schools and the development of social capital

\begin{tabular}{|c|cccc|c|}
\hline $\begin{array}{c}\text { Significant } \\
\text { level }\end{array}$ & $(\mathbf{R})^{2}$ & $\begin{array}{c}\text { Correlation } \\
\text { amount }\end{array}$ & $\begin{array}{c}\text { correlation } \\
\text { dependent }\end{array}$ & $\begin{array}{c}\text { Independent } \\
\text { variable }\end{array}$ & \begin{tabular}{c} 
variable \\
\hline 0.000
\end{tabular} \\
\hline
\end{tabular}

As can be seen from the above table, between two variables of participatory management in schools with social capital-positive there was significant relationship at alpha level of 0.01 . The coefficient of determination calculated showed that the variable of participatory management, explained $0.47 \%$ of the variance of social capital from managers and middle school teachers views in District 3 of Karaj. This result is consistent with previous findings and matched. In this context, the results of this study were consistent with findings Corps (1393) study that showed that there is a significant positive correlation between social capital and participatory management (0.57). Also, the dimensions of social capital had a positive 
and significant relationship with partnership management. The results also were consistent with the findings of Shah Mohammadi and Ali Moradi (2013) that in a research that there was a significant relationship between the communication types by managers and constructive interaction between the partners. Those who have used the dynamic communication style had more freedom of action. In explaining this conclusion, it can be stated that the participation, consultation and consultation of employees pursuant to integrate ideas and abilities and all the things will be done best. When implementation is used in an organization, all employees know themselves respectful, valuable, useful and effective and count themselves as partner to the fate and success of the organization. This will increase staff social capital. They will have more relationship with their colleagues; they trust each other and will have activities in organization. In fact, educational organizations leaders can adopt a participatory leadership style and build trust between individuals through its investment and compliance; listen to the demands of compliance; to participate in decision-making, missions of the organization; raising people through mental development; engaging followers in the organization; giving responsibility to followers and pledged their unflinching, has helped to improve social capital and in that way, in addition to employing people with high human capital, social capital of their organizations also benefit from the advantages.

The second hypothesis: there is positive correlation between participation in decisionmaking in schools and social capital from administrators and teachers views in secondary schools in District 3 of Karaj.

Table 2. The correlation between participation in school decision making and the development of social capital amongst managers and teachers

\begin{tabular}{|c|c|c|c|c|c|}
\hline $\begin{array}{c}\text { Significance } \\
\text { level }\end{array}$ & $(\mathbf{R})^{2}$ & $\begin{array}{c}\text { correlation } \\
\text { amount }\end{array}$ & $\begin{array}{c}\text { Correlation } \\
\text { type }\end{array}$ & $\begin{array}{c}\text { dependent } \\
\text { variable }\end{array}$ & $\begin{array}{c}\text { Independent } \\
\text { variable }\end{array}$ \\
\hline 0.000 & 0.16 & 0.402 & Pearson & social capital & $\begin{array}{l}\text { Participation in } \\
\text { decision- } \\
\text { making in } \\
\text { schools }\end{array}$ \\
\hline
\end{tabular}

As can be seen from the above table, there was a positive correlation between two variables of decision-making in schools and relation with social capital that this correlation is significant at alpha level of 0.01 . The calculated coefficient of determination show that the variable of participation in school decision making explained $0.16 \%$ of the variance of social capital 
amongst managers in middle school teachers in District 3 of Karaj. In this context, the results of this study were consistent with findings of Sepahi (2014) that in a research showed that there was a significant positive correlation between social capital and participatory management (0.57). The dimensions of social capital have a positive and significant correlation with partnership management. The results also with the findings of correspond achieved by Shah Mohammad and Ali Moradi (2013) that in a research showed that there was a significant corelation between communication by managers and constructive interaction between the styles in partners. Those who have used the dynamic communication style had more freedom of action. Decision making is as the key to understanding the complexities of organization and anagement and according to Simon's original ink and decision management and even can be considered synonymous with it. It is clear that the actions and the formation of what is considered interactions are decisions and decision making and all the manager's actions mixed with decision and therefore the management with decision-making are equivalent. From this step, orientation and practical next steps and activities begins (Hazer, 2005). When managers participate their employees in decisions are usually full confidence in their subordinates, communication between subordinates and superiors are very high, subordinates fully involved in the decision-making process. Subordinates freely express their opinions, in this type of system there are a lot of teamwork, all members of the organization are responsible for achieving the goals. Employees through economic rewards and participation in decision-making and goal achievement motivate (Hosseini-Nasab, et al, 2012).

The third sub-hypothesis: there is positive correlation between participatory communication in schools and social capital from administrators and teachers views in area 3 in high school, Karaj.

Table 3. The relationship between participatory communication in schools and development of social capital from principals and teachers view

\begin{tabular}{|c|c|c|c|c|c|}
\hline $\begin{array}{c}\text { Significant } \\
\text { level }\end{array}$ & $(\mathbf{R})^{2}$ & $\begin{array}{c}\text { Correlation } \\
\text { amount }\end{array}$ & $\begin{array}{c}\text { Correlation } \\
\text { type }\end{array}$ & $\begin{array}{l}\text { dependent } \\
\text { variable }\end{array}$ & $\begin{array}{c}\text { Independent } \\
\text { variable }\end{array}$ \\
\hline 0.000 & 0.20 & 0.455 & Pearson & $\begin{array}{l}\text { social } \\
\text { capital }\end{array}$ & $\begin{array}{c}\text { Community } \\
\text { participation in } \\
\text { school }\end{array}$ \\
\hline
\end{tabular}


As can be seen from the above table, there was positive and significant correlation between two variables of participatory communication in schools with social capital. This correlation was significant at the alpha level of 0.01 . The calculated coefficient of determination showed that cooperative associations in schools explain $0.20 \%$ of the variance of social capital amongst managers and middle school teachers in District 3 of Karaj. In this context, the results of this study were consistent with findings of Dad sepahi (2014) that in a study showed that there was a significant positive correlation fits between social capital and participatory management (0.57). The dimensions of social capital had a positive and significant correlation between social investment and partnership management. The results also were in consistent with the findings of Shah Mohammadi and Ali Moradi (2013) that in research achieved that there was a significant relationship between the use of partners' communication by managers and constructive interaction between colleagues. Those who have used the dynamic communication style had more freedom of action. In participatory communication, there is a two-way communication style in which the transmitter and the receiver both (head and subjects) effect from each other, and head try to encourage and motivate their subordinates. For example in cases such as planning, goal investment, job or thinking about the tasks. Discussion space is open between the parties within the organization. Both sides in an environment that is receptive to different opinions and decisions are addressing. In this case, seniority and other factors expertise and organizational status in the relationship between the two sides, pale and so facilitate exchange of information between them and for bilateral is conducted. In fact, the participatory communication of managers or chief delegated responsibility to subordinates and assumed a protective role and prefer to be helped more than the others and pay more attention to other viewpoints (the audience) (Roody and Mohammadi Hossein Nejad, 2013) and Mohammad Hossein Nejad, 1393, p. 12). All of these factors improve relations and cooperation of staff and social capital and social investment will improve naturally.

The fourth sub-hypothesis: there is a positive corelation between participative leadership in the schools and social capital from administrators and teachers views in secondary schools in District 3 of Karaj. 
Table 4. The correlation between participative leadership in schools and the development of social capital amongst managers and teachers

\begin{tabular}{|c|cc|cc|c|}
\hline $\begin{array}{c}\text { Significant } \\
\text { level }\end{array}$ & $(\mathbf{R})^{2}$ & $\begin{array}{c}\text { Correlation } \\
\text { amount }\end{array}$ & $\begin{array}{c}\text { Correlation } \\
\text { type }\end{array}$ & $\begin{array}{c}\text { dependent } \\
\text { variable }\end{array}$ & $\begin{array}{c}\text { Independent } \\
\text { variable }\end{array}$ \\
\hline 0.000 & 0.40 & 0.643 & Pearson & social capital & Participatory \\
& & & & & leadership \\
\hline
\end{tabular}

As can be seen from the above table, there was positive and significant correlation between two variables of participative leadership in schools and social capital. This correlation was significant at alpha level of 0.01 . The calculated coefficient of determination showed that the variable of participative leadership in schools explains $0.40 \%$ of the variance of social capital from managers and middle school teachers in District 3 of Karaj.

In this context, the results of this study were consistent with findings of Dad sepahi (2014) that in a study showed that there was a significant positive correlation fits between social capital and participatory management (0.57). The dimensions of social capital had a positive and significant correlation between social investment and partnership management. The results also were in consistent with the findings of Shah Mohammadi and Ali Moradi (2013) that in research achieved that there was a significant relationship between the use of partners' communication by managers and constructive interaction between colleagues. Participative style managers can motivate their subordinates to do what they can. Stone and his colleagues believe that this type of leadership motivate staff in order to go beyond their own interests and make them to have interests of the group's work. In general, corporate executives, inspire and motivate followers with good behavior and time to conduct training and communicate with people, compassionate and serious consideration to the demands of followers, growth and development of their capabilities. These characteristics and behaviors in turn makes the employees feel responsible beyond what is necessary for them to do their job, and to show more cooperation and also have more activity in the service of achieving the organization's goals. In general it can be said that participatory managers through motivation make followers to actively participate in workplace and because of their behaviors and views, encourageb their employees and it is logical also under rgis conditions followers do better in their working environment vecause they could trust to organizations and have good relationships with their managers and colleagues. 
Fifth hypothesis: there is positive corelation between participatory structure in schools and social capital in administrators and teachers view in secondary schools in District 3 of Karaj.

Table 5. Correlation between the participatory structure in schools and growth of social capital from the perspective of principals and teachers in schools

\begin{tabular}{|c|c|c|c|c|c|}
\hline $\begin{array}{c}\text { Significant } \\
\text { level }\end{array}$ & $(\mathbf{R})^{2}$ & $\begin{array}{c}\text { Correlation } \\
\text { amount }\end{array}$ & $\begin{array}{c}\text { Correlation } \\
\text { type }\end{array}$ & $\begin{array}{c}\text { dependent } \\
\text { variable }\end{array}$ & $\begin{array}{c}\text { Independent } \\
\text { variable }\end{array}$ \\
\hline 0.000 & 0.22 & 0.471 & Pearson & social capital & participatory \\
& & & & & structure \\
\hline
\end{tabular}

As can be seen from the above table there was a positive and significant correlation with social capital and participatory structures in schools. This correlation was significant at alpha level of 0.01 . The calculated coefficient of determination showed that the variable of collaborative structure in schools explained $0.22 \%$ of the variance of social capital amongst managers and teachers of middle school in District 3 of Karaj.

In this context, the results of this study were consistent with findings of Dad sepahi (2014) that in a study showed that there was a significant positive correlation fits between social capital and participatory management (0.57). The dimensions of social capital had a positive and significant correlation between social investment and partnership management. The results also were in consistent with the findings of Shah Mohammadi and Ali Moradi (2013) that in research achieved that there was a significant relationship between the use of partners' communication by managers and constructive interaction between colleagues. Those who have used the dynamic communication style had more freedom of action. Despite the reasonable structure, the staff can obtain information faster and faster decision-making and speed of reaction will be faster against environmental variables. But the structure that focuses on of the complex, high formality and organizational, not only prevents the flow of enterprise information, but also lead employee dissatisfaction, slowness of the decision, a loss of competitiveness, reduce social interaction of employees, undermining knowledge management and the result will be slow to respond to environmental variables (Chen and Huang, 2006). In defining the rsults of this study it can be said that if the activities and schools events be shown in an exact format of Instructions, circulars or traditional methods and codified and teachers be expected to always apply them in the same way, more and more organizations recognize deeper. These formal investigations, controls and rigid structures as 
an obstacle against the improvement of social capital are placed in schools whereby the individual 'performance is limited.

Sixth hypothesis: there was a positive correlation between participatory management in schools and the development of social capital amongst managers and middle school teachers in District 3 of Karaj

Table 6. The correlation between corporate control in schools and development of social capital from administrators and teachers view

\begin{tabular}{|c|c|c|c|c|c|}
\hline $\begin{array}{c}\text { Significant } \\
\text { level }\end{array}$ & $(\mathbf{R})^{2}$ & $\begin{array}{c}\text { Correlation } \\
\text { amount }\end{array}$ & $\begin{array}{c}\text { Correlation } \\
\text { type }\end{array}$ & $\begin{array}{c}\text { dependent } \\
\text { variable }\end{array}$ & $\begin{array}{c}\text { Independent } \\
\text { variable }\end{array}$ \\
\hline 0.000 & 0.20 & 0.453 & Pearson & social capital & $\begin{array}{c}\text { Participation } \\
\text { control }\end{array}$ \\
\hline
\end{tabular}

As can be seen from the above table, there was positive and significant correlation between two variables of social capital and participatory control in schools. This correlation was significant at alpha level of 0.01 . The calculated coefficient of determination showed that participatory control variable in schools, explains $0.20 \%$ of the variance of social capital amongst managers and middle school teachers in District 3 of Karaj. In this context, the results of this study were consistent with findings of Dad sepahi (2014) that in a study showed that there was a significant positive correlation fits between social capital and participatory management (0.57). The dimensions of social capital had a positive and significant correlation between social investment and partnership management. The results also were in consistent with the findings of Shah Mohammadi and Ali Moradi (2013) that in research achieved that there was a significant relationship between the use of partners' communication by managers and constructive interaction between colleagues. Those who have used the dynamic communication style had more freedom of action. Self-control, is creating a state within the individual makes him inclined to perform his duties, without any external cause him under control. The target that is followed in Self-control is providing a healthy personality that has reached maturity, and show strength against all kinds of problems and in addition to his workplace career will be self-control. And it will not be possible unless the suitable substrates to be provided to self-control to be institutionalized in the organization. The staff are somewhat flexible because trust relative to them. Manager issued based on regulations and orders and makes decision. The staff has been entrusted to task somewhat freedom. Chairman 
is charitable and paternal to subordinate. Trust between boss and subordinate is low and because of his contacts with the subordinate behavior and director of caution stems (Choopani, 2011).

\section{SUGGESTIONS}

The results showed that there was positive correlation among the use of participatory management in schools, participatory decision making, participatory communication, collaborative, participative leadership, participatoty control, growth of social investent amongst managers and middle school teachers in District 3 Karaj.

For this purpose, it is suggested that;

1. it is recommended to district 3 school principals of Karaj city, that specific goal or ideal to be designed light and detailed precision to keep their followers to be able to recognize the current situation, analyze it and even be able to motivate and willingness to work beyond the official job description be.

2. District 3 school principals of Karaj city should create optimistic image about the future in teachers in schools to make them more involved in achieving the goalsaAnd participate because this optimistic thinking about the future makes that employees become more motivated to do the job and encourages his subordinates have higher performance.

3. Create a supportive and friendly environment to increase employee satisfaction and thus increase effectiveness.

4. Managers of district 3 of Karaj city schools try to moving from traditional management style and on a participative management style and behavior patterns of social capital improvement prepare the ground for this style.

5. The decisions of the individual; one-way communication (from top to bottom) and direct supervision by school administrators of Area 3 in Karaj city reduce to a minimum.

6. Take group decisions, network communications, and self-control by the city of Karaj District 3 school principals and administrators should be encouraged.

7. Encourage the formation of working groups on education that the nature of staff work moves from individual nature to nature groups to the collective and movement nature.

8. It is suggested that in encourage new ideas in the organization, managers should be eager to hear suggestions from staff and resources to test many new ideas invest. Therefore, school administrators need to reorganize the school system and funding proposals and consider special facilities for it. 
9. Managers should listen to the views presented by staff and use useful and practical comments to adopt and thereby encourage employees to submit comments.

\section{REFERENCES}

[1] Andishmand Vida. 2009. Identify the components of social capital in universities in order to promote its Model, Journal of Educational Leadership and Management, 3 (2 (8)): 934.

[2] Choopani Haider. 2011. The relationship between transformational leadership and organizational innovation orientation in Alborz Insurance Company, thesis Department of Education, Faculty of Education and Psychology, Tehran University.

[3] Hazer Manoochehr. 2005. Management decisions, Tehran: State Management Training Center.

[4] Hassanpour Akbar, Niakan Nazila. 2007. Social capital and gender in the workplace. Monthly devise. 183. Number 41-45.

[5] Hosseininasab Seyed Davood, Farnia Mohammad Ali, molana firoozeh. 2012. To investigate the relationship between leadership styles (based on the theory Likert) job satisfaction of school administrators and teachers in secondary schools in the academic year 89-88 Pars-Abad city. Educational Sciences Journal, 5 (20): 13-32.

[6] Dad Sepahi Karim. 2014. Social capital and its relationship with collaborative management of middle school teachers in the city of Birjand, Master's thesis, University of Education and Psychology, University of Birjand.

[7] Damoori Dariush, Mansouri Hussein, Taheri Dimna Mohsen. 2008. Evaluate the relationship between knowledge management and social capital in the Islamic University from the viewpoint of faculty members of Yazd University. Management at the Islamic University 41: 44-64.

[8] Roody Komeil, Mohammadi Hosseini Nejad, Malihe. 2014. Model appropriate organizational communications, communications management magazine, 48: 11. 15.

[9] Zare Khalili Mojtaba. 2011. The relationship between social capital and knowledge management in the Asia Insurance Company. Master's thesis, Faculty of Psychology and Educational Sciences, Tehran University.

[10] Shah Mohammadi Abdolreza, Ali Moradi Masood. 2013. Effect of management communication style in the interaction between individual employees, Media Studies, 8 (22): 162-171. 
[11] Sharifian Thani Maryam. 2001. Social capital: the main concepts and theoretical framework. Journal of Social Welfare, 2: 5-8.

[12] Sayadi Gholamali. 2009. Investigate the relationship between social capital and organizational learning (case study experts Tehran University) proper task of promoting a Thran.payan. Faculty of Psychology and Educational Sciences.

[13]Alavi Seyed Babak. 2001. The role of social capital in development. Scientific journal extension prudence, 12 (116): 34-40.

[14]Faraji deh sorkhi Hatem. 2009. A comparative study of organizational social capital in the College of Humanities and Social and Behavioral Sciences of Tehran University of experts. Master's thesis, Faculty of Psychology and Educational Sciences, Tehran University.

[15]Feizi Tahereh, Kavoosi Ismail, Ali Najafi Zeinab. 2010. The relationship between social capital and participatory management at the University of Medical Sciences, Journal of Management Studies, 21 (86): 103-120.

[16]Feizi Mahdi. 2006. A comparative study of the efficacy of participative management style and management of traditional creativity Secretary: A Case Study of Sanandaj city high school, Master's thesis, Faculty of Psychology and Educational Sciences, Shiraz University.

[17] Mohammadi Mohammad Ali. 2005. The measurement of social capital. Tehran. University of Welfare and Rehabilitation Sciences.

[18] Manzoor Davood, Yadipour Mehdi. 2008. Social capital of the social and economic development. Journal Jasmine strategy. 15: 140-162.

[19]Nadi Mohammad Ali, Moshfeghi Nozhat Al zaman. 2009. Recognition of teachers' perceptions of relationships and emotional dimensions of organizational trust and continuous commitment to provide a structural equation model of proper education organization. Journal of Leadership and Management, Islamic Azad University Vahdgrmsar, 3 (4): 155-174.

[20]Nateghpour Mohammad Javad, Firouz Abadi Seyed Ahmad. 2006. Social capital formation and meta-analysis of influencing factors, Social Science Quarterly, 28: 160190.

[21] Adams, H. L (2006). Mindful Use as a Link between Social Capital and Organizational Learning: An Empirical Test of the Antecedents. Dissertation submitted to the Faculty of 
the Graduate School of the University of Maryland, College Park in partial fulfillment of the requirements for the degree of $\mathrm{PhD}$ in Information Systems.

[22] Adler, Paul S. \& Kwon, Seok-Woo (2002). Social Capital: Prospects for a new Concept. Academy of Management Review, 27(1):17-40.

[23] Hammer A, Ommen O, Röttger J, Pfaff H. (2012). The relationship between transformational leadership and social capital in hospitals--a survey of medical directors of all German hospitals. Journal of Public Health Management \& Practice, 18(2):175180.

[24] Hamzezadehafkham, G,. Moharramzadeh, M and Alam, S (2013). Relationship between organizational justice and social capital of the department of sports and youth of West Azerbaijan province, Scholars Research Library Annals of Biological Research, 4 (8):112-116

[25] Hoffman, James J. Hoelscher, Mark L. and Sherif, Karma (2005). Social capital, knowledge management, and sustained superior performance. Journal of Knowledge Management. 9(3): 93-100.

[26]Lazarova, M \& Taylor, S (2008). Boundary less careers, social capital and knowledge management: Implications for organizational performance. Journal of Organizational Behavior. 30(1): 119-139.

[27] Schneider, Joe Anne (2009). Organizational social capital and nonprofits. Nonprofit and Voluntary Sector Quarterly, 38(4), pp.643-662.

[28] Timberlake, S. (2005). Social Capital and Gender in Workplace. Journal of Management Development, 24 (1):34-44.

\section{How to cite this article:}

Abbasi E and Keshavarz Noori S. Study on the relationship between participatory management in schools and teachers' development of social capital from managers and teachers views of secondary school teachers Karaj district 3. J. Fundam. Appl. Sci., 2016, $8(3 S), 230-246$. 